\title{
Physical and chemical characteristics of melon in organic farming
}

\author{
Rosete A. G. Kohn¹, Carlos R. Mauch², Tânia B. G. A. Morselli, \\ Cesar V. Rombaldi ${ }^{4}$, Willian S. Barros ${ }^{5}$ \& V. Sorato ${ }^{6}$ \\ ${ }^{1}$ Centro de Ciências Exatas e Ambientais/Universidade da Região da Campanha. Bagé, RS. E-mail: rkohn@ibest.com.br (Autor correspondente) \\ ${ }^{2}$ Departamento de Fitotecnia/Faculdade de Agronomia Eliseu Maciel/Universidade Federal de Pelotas. Pelotas, RS. E-mail: crmauch@gmail.com \\ ${ }_{3}^{3}$ Departamento de Solos/Faculdade de Agronomia Eliseu Maciel/Universidade Federal de Pelotas. Pelotas, RS. E-mail: tamor@uol.com.br \\ ${ }^{4}$ Departamento de Ciência e Tecnologia Agroindustrial/Faculdade de Agronomia Eliseu Maciel/Universidade Federal de Pelotas. Pelotas, RS. E-mail: \\ cesarvrf@ufpel.edu.br \\ ${ }^{5}$ Departamento de Matemática e Estatística/Instituto de Física e Matemática/Universidade Federal de Pelotas. Pelotas, RS. E-mail: willian.barros@ufpel.edu.br \\ ${ }^{6}$ Universidade da Região da Campanha. Bagé, RS. v.sorato_agro@hotmail.com (Bolsita de PIIC)
}

\section{Key words:}

Cucumis melo var. inodorus organic fertilization

postharvest

quality

phytochemicals

\begin{abstract}
A B S T R A C T
Melon farming is characterized as an important family agriculture activity and the organic production of fruits and vegetables has shown a large growth in terms of areas in Brazil and around the world. This work aimed to study the postharvest quality of melon cultivated in an organic system. The organic treatments constituted of base fertilizer with cattle manure vermicompost (recommended dose, $1 / 2$ dose and double dose) plus the use of biofertilizer (sprayed or sprayed + irrigated), and an additional treatment with chemical fertilization. The postharvest quality was evaluated through physico-chemical and phytochemical attributes. The organic management with half the recommended dose of vermicompost plus the sprayed biofertilizer and the chemical fertilization management produced fruits with higher levels of sugar, total carotenoids, ascorbic acid and folates, obtaining more balanced fruits, with a better phytochemical quality. The antioxidant capacity was defined mainly by the presence of the phenolic compounds, which were influenced by the type and the dose of the evaluated fertilizers, with superiority in the organic treatments with double the dose of cattle manure vermicompost.
\end{abstract}

Palavras-chave:
Cucumis melo var. inodorus
adubação orgânica
pós-colheita
qualidade
fitoquímicos

\section{Palavras-chave:}

dorus

qualidade

fitoquímicos

\section{Características físicas e químicas de melão em cultivo orgânico}

\section{R E S U M O}

A cultura do melão se caracteriza como importante atividade na agricultura familiar; ressalta-se que a produção orgânica de frutas e hortaliças tem apresentado, no Brasil e no mundo, grande crescimento em área. Este trabalho teve, como objetivo, estudar a qualidade pós-colheita de melão cultivado em sistema orgânico. Os tratamentos orgânicos foram constituídos por adubação de base com vermicomposto bovino (dose recomendada, 1/2 da dose e dobro da dose) mais utilização de biofertilizante na forma pulverizada ou pulverizada e regada, além de um tratamento adicional com adubação química. A qualidade pós-colheita foi avaliada através de atributos físico-químicos e fitoquímicos. $\mathrm{O}$ manejo orgânico com a metade da dose de húmus recomendada mais o biofertilizante pulverizado e o manejo de adubação química produziram frutos com maiores teores de açúcares, carotenoides totais, ácido ascórbico e ácido fólico obtendo-se frutos mais equilibrados e de melhor qualidade fitoquímica. A capacidade antioxidante foi definida, sobretudo pela presença dos compostos fenólicos influenciados pelo tipo e pela dose das adubações, com superioridade nos tratamentos orgânicos com o dobro da dose de húmus. 


\section{INTRODUCTION}

Organic production occupies an area of 37.2 million ha, including transition areas. In Latin America, the area was 6.9 million ha in 2011, which correspond to $18 \%$ of the global organic area. The main countries are Argentina (4.2 million ha), Uruguay (0.9 million ha) and Brazil (0.7 million ha). Brazil has 1.8 million ha with organic certification (including native areas). North and south regions amount to $49 \%$ of the total organic production units (Willer et al., 2013).

The production of melon in Brazil was equal to $575,386 \mathrm{t}$ in $2012 / 2013$, for an area of 22,810 ha, located mostly in the northeast region. The states of Rio Grande do Norte and Ceará are the main producers, while Rio Grande do Sul occupies the forth position. Nearly one third of the national production is directed to the internal market (ABF, 2014).

According to Williams (2002), among the main comparative studies on nutrition, just a limited number have compared the nutritional composition of fruits from organic and conventional systems with a good control of the variables.

In general, there is a tendency for reduction in the content of nitrates and increase in the contents of vitamin $C$ in organically produced foods, especially leafy vegetables, which suggests that further research is necessary in this area.

Toor et al. (2006) studied the influence of different types of fertilizers on the main antioxidant components of tomatoes and concluded that fertilizer sources can have an expressive effect on the concentration of these nutrients. The use of organic fertilizers increased the levels of total phenolic compounds and ascorbic acid.

The quality of melon fruits involves attributes related to characteristics of the pulp, such as firmness, content of soluble solids, subjective evaluation regarding the appearance (external and internal), content of soluble sugars (reducing and total) (Filgueiras et al., 2000) and, more recently, the presence of health-promoting phytonutrients, such as ascorbic acid, folic acid and betacarotene (precursor of the vitamin A), predominant in cultivars with salmon-colored pulp (Lester \& Hodges, 2008).

Still regarding the qualitative aspects, fruits and vegetables contain distinct antioxidant substances, whose activities have been proved in the last years. The presence of phenolic compounds, such as flavonoids, phenolic acids and anthocyanins, besides the known vitamins $\mathrm{C}, \mathrm{E}$ and carotenoids, contribute to the beneficial effects of these foods on human health (Podsedek, 2007).

The content of polyphenols in vegetables, similarly to the contents of other phytochemicals, can be influenced by many factors, such as variety, climatic conditions, cultural practices, maturity and storage conditions (Podsedek, 2007; Balisteiro et al., 2013). The cultivation under biotic and abiotic stress can stimulate the synthesis of bioactive compounds ( $\mathrm{Oh}$ et al., 2009).

In this context, this study aimed to evaluate the ecological inputs for the organic production of melon and their effects on fruit quality, providing farmers with safer management options, in order to strengthen the credibility of the system.

\section{Material AND Methods}

The study was carried out at the Center of Rural Sciences of the University of the Campanha Region, Bagé-RS, Brazil. The experiment was installed in an area of $280 \mathrm{~m}^{2}$, using the hybrid Goldex $\mathrm{F}^{\circ}{ }^{\circ}$ of 'Valenciano' melon (Cucumis melo, var. inodorus). Plants were conducted in beds under drip irrigation and mulching with a spacing of $2.0 \times 0.5 \mathrm{~m}$, totaling a density of 10,000 plants ha ${ }^{-1}$. Melon was planted using seedlings produced in a protected environment, which were transplanted on November 8th 2012, with two true leaves. Plants were conducted without pruning or thinning.

The experiment was set in a randomized block design with four replicates and seven treatments. The treatments constituted of three basal fertilizations, based on the recommendation for the nitrogen demand, and two forms of topdressing application of biofertilizer (spray and spray + irrigation), besides the control treatment, with chemical fertilization. The experiment was composed of 28 plots, with 10 plants each, totaling 280 plants. The recommended dose for the application of cattle manure vermicompost (CMV) was $1.9 \mathrm{~kg} \mathrm{~m}^{-2}$. For the $0.25 \mathrm{~m}^{2}$ planting pits, the applied amounts were $475 \mathrm{~g} \mathrm{pit}^{-1}$ (dose), $237.5 \mathrm{~g} \mathrm{pit}^{-1}$ (1/2 dose) and $950 \mathrm{~g} \mathrm{pit}^{-1}$ ( $2 \mathrm{x}$-dose). The treatments with biofertilizers were composed of weekly sprayings, which started 20 days after transplantation (DAT), totaling six.

In the treatments with biofertilizers, $100 \mathrm{~mL}$ plant $^{-1}$ were applied at 32, 56 and 57 DAT. The conventional treatment followed the recommendation of ROLAS (2004), with the application in the row, considering the dose in $\mathrm{g} \mathrm{m}^{-2}: 219 \mathrm{~g}$ of diammonium phosphate, $272 \mathrm{~g}$ of potassium chloride $(\mathrm{KCl})$ and topdressing application of nitrogen $(\mathrm{N})$ at $33 \mathrm{DAT}$, using $7.95 \mathrm{~g}$ of urea plant $\mathrm{t}^{-1}$.

The evaluated treatments were: $\mathrm{T} 1$ - basal fertilization with cattle manure vermicompost (dose) + sprayed biofertilizer; $\mathrm{T} 2$ - basal fertilization with cattle manure vermicompost (dose) + sprayed and irrigated biofertilizer; T3 - basal fertilization with cattle manure vermicompost ( $1 / 2$ dose $)+$ sprayed biofertilizer; T4 - basal fertilization with cattle manure vermicompost $(1 / 2$ dose $)+$ sprayed and irrigated biofertilizer; T5 - basal fertilization with cattle manure vermicompost $(2 \mathrm{x}$-dose $)+$ sprayed biofertilizer; $\mathrm{T} 6$ - basal fertilization with cattle manure vermicompost (2x-dose) + sprayed and irrigated biofertilizer; and the additional treatment T7 - conventional fertilization, according to ROLAS (2004).

After the main harvest (67 DAT), four fruits were randomly selected in the area, with three replicates per treatment and the following parameters were evaluated: external and internal appearance, $\mathrm{pH}$, total titratable acidity, total soluble solids, soluble solids/acidity, pulp firmness, reducing sugars, total sugars, sucrose, total phenolic compounds, total carotenoids, antioxidant capacity, ascorbic acid and folates.

External and internal appearances were evaluated through subjective analysis using a rating scale, according to Menezes (1998). The evaluation of pulp firmness (PF), expressed in Newton (N), followed the methodology of Filgueiras et al. (2000). For the other analyses, samples were prepared by removing the edible pulp of four equidistant slices of each 
fruit, which were divided into pieces. A 10-g sample was removed from the middle part of one of the four fruits and was immediately frozen with liquid nitrogen and kept in a domestic freezer. The rest of the sample was homogenized in a domestic centrifugal machine and the biochemical analyses were performed in the juice, in three replicates.

The $\mathrm{pH}$ was measured directly in the juice with a digital potentiometer (AOAC, 1992). Total titratable acidity (TTA) was measured through titration and expressed in percentage of citric acid (\% CA) (AOAC, 1992). The total soluble solids (TSS) were measured in a refractometer with automatic temperature correction (AOAC, 1992). The ratio between total soluble solids and total titratable acidity (TSS/TTA) was obtained by calculating the relationship between the results of these variables (Filgueiras et al., 2000).

The analysis of bioactive compounds, total sugars, reducing sugars and sucrose was performed at the Laboratory of Fruits and Vegetables Postharvest of the Department of Agroindustrial Science and Technology of the 'Eliseu Maciel' College of Agriculture at the Federal University of Pelotas (DCTA/FAEM/UFPEL), using $10 \mathrm{~g}$ samples, according to the methodologies described below.

Total phenolic compounds (TPC) were quantified using the Folin-Ciocalteu reagent, according to the method of Swain \& Hillis (1959), and the results were expressed in $\mathrm{mg}$ of gallic acid equivalent per $100 \mathrm{~g}$ of fresh fruit (mg GAE $100 \mathrm{~g}^{-1}$ ). The antioxidant capacity (AC) was determined based on the capture of the DPPH radical, according to Fetter et al. (2010), and expressed in $\mu \mathrm{g}$ of Trolox equivalent $\mathrm{g}^{-1}$ of dry fruit $(\mu \mathrm{g} \mathrm{TE}$ $\mathrm{g}^{-1}$. The total carotenoids (TC) were extracted according to Rodriguez-Amaya (2001) and expressed in $\mathrm{mg}$ of $\beta$-carotene per $100 \mathrm{~g}$ of dry weight $\left(\mathrm{mg} 100 \mathrm{~g}^{-1}\right)$. The content of ascorbic acid (ASC) was quantified using a high-efficiency liquid chromatography system (HPLC-Shimadzu), equipped with automatic injector and UV-visible detector (254 nm), and expressed in $\mathrm{mg} 100 \mathrm{~g}^{-1}$ (Vinci et al., 1995). The folates (FOL) were analyzed according to the method of Catharino et al. (2006), and the results were expressed in $\mu \mathrm{g} 100 \mathrm{~g}^{-1}$ of the sample. The contents of total sugars (TSug), reducing sugars (RSug) and sucrose (SUC) were expressed in $\% \mathrm{~m} \mathrm{~m}^{-1}$ (AOAC, 1992).

A randomized block design with four replicates was used for the field experiment and a completely randomized design with three replicates was used for the postharvest evaluations, after the main harvest (67 DAT). For the statistical analysis of the results, the software Statistix, version 9.0, was used. Means were compared through the ANOVA $(\mathrm{p}<0.05)$ and the orthogonal contrasts defined by the analysis: $\mathrm{C} 1$ - conventional $\mathrm{x}$ organic; $\mathrm{C} 2$ - sprayed $\mathrm{x}$ sprayed + irrigated; $\mathrm{C} 3$ - dose $\mathrm{x} 1 / 2$ dose; $\mathrm{C} 4$ - dose $\mathrm{x}$ double dose; and $\mathrm{C} 5-1 / 2$ dose $\mathrm{x}$ double dose, evaluated by the Bonferroni t-test.

\section{Results AND Discussion}

According to the analysis of variance, there was a highly significant effect of the treatments $(\mathrm{p}<0.001)$ for the quality attributes, such as the contents of TSug, RSug and SUC. When the chemical composition was detailed, with emphasis on the secondary compounds, the dependent variables were also affected by the treatments. This occurred for the contents of TPC, TC, ASC, FOL and, as a consequence, AC. The treatments did not influence the responses of other attributes, such as ExtAp, PF, pH, TTA, TSS and the TSS/ TTA, which were similar between the treatments with mean values of $1.51,18.33 \mathrm{~N}, 5.93,0.10 \% \mathrm{CA}, 9.88^{\circ} \mathrm{Brix}$ and 98.57 , respectively (Table 1 ).

According to comparison of the treatments by the orthogonal contrasts (Table 2), the contents of TSug in fruit pulps was significantly different between sprayed and sprayed and irrigated treatments (C2) and between the different CMV doses (C3, C4 and C5). For T1, T3 and T5, the sprayed biofertilizer showed a mean value of $9.34 \% \mathrm{~m} \mathrm{~m}^{-1}$ of TSug, higher than that for sprayed and irrigated treatment, with $8.84 \% \mathrm{~m} \mathrm{~m}^{-1}$. For the studied CMV doses, the treatments T3 and T4 (1/2 dose) produced fruits with TSug differences of $1.58 \% \mathrm{~m} \mathrm{~m}^{-1}$ compared with T5 and T6 (2x-dose) and 0.59\% $\mathrm{m} \mathrm{m}^{-1}$, compared with T1 and T2 (dose) (Table 2). RSug contents partially followed the behavior of TSug and differed for the contrasts $\mathrm{C} 1, \mathrm{C} 2, \mathrm{C} 4$ and $\mathrm{C} 5$ (Table 2). The conventional treatment (T7) showed difference of $0.4 \% \mathrm{~m} \mathrm{~m}^{-1}$ from the mean of the organic treatments. The treatments with sprayed biofertilizer were $0.22 \% \mathrm{~m} \mathrm{~m}^{-1}$ higher than the sprayed and irrigated treatments (T2, T4 and T6) and, among the doses, the treatments T5 and T6 showed the lowest means of TSug when compared with the groups $\mathrm{T} 1$ and $\mathrm{T} 2$, differing by $0.73 \%$

Table 1. Analysis of variance for the studied post-harvest parameters in the production of the melon hybrid Goldex , in organic and conventional production systems

\begin{tabular}{|c|c|c|c|c|c|}
\hline Parameters & Abbrev. & Units & $F$ & Overall mean & CV \\
\hline Total Sugars & TSug & $\% \mathrm{~m} \mathrm{~m}^{-1}$ & $54.50(p=0.00)$ & 9.34 & 2.57 \\
\hline Reducing Sugars & RSug & $\% \mathrm{~m} \mathrm{~m}^{-1}$ & $19.60(p=0.00)$ & 4.86 & 3.59 \\
\hline Sucrose & SUC & $\% \mathrm{~m} \mathrm{~m}^{-1}$ & $15.41(p=0.00)$ & 4.48 & 6.48 \\
\hline Total Phenolic Compounds & TPC & mg GAE $100 g^{-1}$ & $74.32(p=0.00)$ & 12.26 & 3.06 \\
\hline Total Carotenoids & TC & $\mathrm{mg} 100 \mathrm{~g}^{-1}$ & $82.04(p=0.00)$ & 20.19 & 3.06 \\
\hline Antioxidant Capacity & $A C$ & $\mu \mathrm{g}$ TE $g^{-1}$ & $34.60(p=0.00)$ & 17.37 & 2.86 \\
\hline Ascorbic Acid & ASC & $\mathrm{mg} 100 \mathrm{~g}^{-1}$ & $19.91(p=0.00)$ & 13.04 & 4.33 \\
\hline Folates & FOL & $\mu \mathrm{g} 100 \mathrm{~g}^{-1}$ & $23.31(p=0.00)$ & 5.37 & 4.89 \\
\hline External Appearance & ExtAp & Índex & $2.09(p=0.12)$ & 1.5 & 13.97 \\
\hline Pulp Firmness & $\mathrm{PF}$ & $\mathrm{N}$ & $1.99(p=0.13)$ & 18.33 & 9.27 \\
\hline $\mathrm{pH}$ & $\mathrm{pH}$ & $\mathrm{pH}$ & $0.34(p=0.90)$ & 5.93 & 1.58 \\
\hline Total Titratable Acidity & TTA & $\%$ CA & $1.67(p=0.20)$ & 0.10 & 7.14 \\
\hline Total Soluble Solids & TSS & ${ }^{\circ}$ Brix & $1.26(p=0.34)$ & 9.88 & 5.77 \\
\hline Ratio of Total Soluble Solids/Total Acidity & TSS/TTA & index & $2.44(p=0.08)$ & 98.57 & 9.89 \\
\hline
\end{tabular}

Abbrev. - Abbreviation; $p<0.05$ - significant; $p<0.01$ and $p<0.001$ - highly significant; $F$ - Snedecor's F value 
Table 2. Mean contents of total sugars (TSug, \% $\mathrm{m} \mathrm{m}^{-1}$ ); reducing sugars (RSug, \% $\left.\mathrm{m} \mathrm{m}^{-1}\right)$; sucrose (SUC, \% $\left.\mathrm{m} \mathrm{m} \mathrm{m}^{-1}\right)$; total phenolic compounds (TPC, mg GAE $100 \mathrm{~g}^{-1}$ ); total carotenoids (TC, mg $100 \mathrm{~g}^{-1}$ ); ascorbic acid (ASC, mg 100g-1); folates

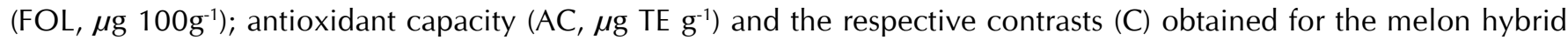
Goldex ${ }^{\circledR}$, cultivated in organic and conventional systems

\begin{tabular}{|c|c|c|c|c|c|c|c|c|}
\hline Treatments & TSug & RSug & SUC & TPC & TC & ASC & FOL & AC \\
\hline $\mathrm{T} 1$ & 9.53 & 5.30 & 4.23 & 12.00 & 19.73 & 11.90 & 5.33 & 18.00 \\
\hline T2 & 8.93 & 4.83 & 4.10 & 12.40 & 17.30 & 12.73 & 4.73 & 17.43 \\
\hline T3 & 10.50 & 5.30 & 5.20 & 10.33 & 24.10 & 14.50 & 5.73 & 15.30 \\
\hline T4 & 9.13 & 4.77 & 4.37 & 10.70 & 20.77 & 14.13 & 6.07 & 15.03 \\
\hline T5 & 8.00 & 4.13 & 3.87 & 14.13 & 17.40 & 11.87 & 4.77 & 18.87 \\
\hline T6 & 8.47 & 4.47 & 4.00 & 15.30 & 17.17 & 11.27 & 4.53 & 19.53 \\
\hline $\mathrm{T} 7$ & 10.80 & 5.20 & 5.60 & 11.03 & 24.83 & 14.90 & 6.43 & 17.43 \\
\hline 6 & 0.14 & 0.10 & 0.17 & 0.22 & 0.36 & 0.33 & 0.15 & 0.29 \\
\hline Contrasts & $\hat{\mathbf{Y}}$ & $\hat{\mathbf{Y}}$ & $\hat{\mathbf{Y}}$ & $\hat{\mathbf{Y}}$ & $\hat{\mathbf{Y}}$ & $\hat{\mathbf{Y}}$ & $\hat{\mathbf{Y}}$ & $\hat{\mathbf{Y}}$ \\
\hline C1 & $1.71^{\mathrm{ns}}$ & 0.40 ** & $1.30^{\mathrm{ns}}$ & $-1.45^{\mathrm{ns}}$ & $5.42^{\mathrm{ns}}$ & $2.17 * *$ & $1.24^{\text {ns }}$ & 0.07 * \\
\hline C2 & $0.5 * *$ & 0.22 * & $0.28^{\mathrm{ns}}$ & $-0.68 * *$ & $2.00 * * *$ & 0.04 ns & $0.17^{\text {ns }}$ & $0.06^{\text {ns }}$ \\
\hline C3 & $-0.59 * *$ & $0.033^{\text {ns }}$ & -0.62 ** & $1.74^{* * *}$ & $-3.92 * * *$ & $-2.00 * * *$ & -0.87 ** & 2.56 *** \\
\hline C4 & $0.99 * \star \star$ & $0.77^{\star \star \star}$ & $0.23^{\mathrm{ns}}$ & $-2.52 * \star \star$ & $1.24^{\star \star \star}$ & 0.75 * & $0.38^{*}$ & -1.48 ** \\
\hline C5 & 1.58 *** & $0.73^{* * *}$ & 0.84 ** & $-4.26 * * *$ & 5.16 *** & $2.75 * * *$ & $1.25 * * *$ & $-4.04 * * *$ \\
\hline
\end{tabular}

Contrasts are significant if $p<0.05\left(^{\star}\right)$, highly significant if $p<0.01\left(^{* \star}\right)$ or $p<0.001\left(^{* \star \star}\right)$, and not significant (ns) by Bonferroni t-test; C1 - Conventional (T7) vs Organic (T1,T2,T3,T4,T5,T6); C2 - Sprayed (T1,T3,T5) vs Sprayed and Irrigated (T2,T4,T6); C3 - Dose (T1,T2) vs 1/2 dose (T3,T4); C4 - Dose (T1,T2) vs Double dose (T5,T6); C5 - 1/2 Dose (T3,T4) vs Double dose (T5,T6); T1 [recommended dose of cattle manure vermicompost (CMV dose) + sprayed biofertilizer]; T2 [CMV dose + sprayed and irrigated biofertilizer]; T3 [1/2 CMV dose + sprayed biofertilizer]; T4 [ $1 \frac{1}{2}$ CMV dose + sprayed and irrigated biofertilizer]; T5 [2x CMV dose + sprayed biofertilizer]; T6 [2x CMV dose + sprayed and irrigated biofertilizer]; T7 [conventional fertilization]

$\mathrm{m} \mathrm{m}^{-1}$, and $\mathrm{T} 3$ and $\mathrm{T} 4$, differing by $0.77 \% \mathrm{~m} \mathrm{~m}^{-1}$, while these two did not differ.

SUC content was affected by the doses and showed significant C3 and C4 contrasts. T3 and T4 (1/2 CMV dose) showed higher SUC contents, with a difference of $0.84 \% \mathrm{~m}$ $\mathrm{m}^{-1}$ compared with T5 and T6 (2x CMV dose) and $0.62 \% \mathrm{~m}$ $\mathrm{m}^{-1}$ compared with $\mathrm{T} 1$ and T2 (CMV dose), similarly to the behavior of TSug.

TPC contents showed a behavior contrary to the one of TSug and were significantly different between sprayed and sprayed + irrigated treatments $(\mathrm{C} 2)$, where the latter produced fruits with TPC of $0.68 \mathrm{mg} \mathrm{GAE} 100 \mathrm{~g}^{-1}$, which is higher than the TPC of the former. For the CMV doses, the TPC was higher for T5 and T6 (2x CMV dose), with a value of $14.72 \mathrm{mg} \mathrm{GAE}$ $100 \mathrm{~g}^{-1}$, compared with $12.20 \mathrm{mg}$ GAE $100 \mathrm{~g}^{-1}$ for T1 and T2 (dose) and $10.46 \mathrm{mg} \mathrm{GAE} 100 \mathrm{~g}^{-1}$ for T3 and T4 ( $1 / 2 \mathrm{CMV}$ dose),

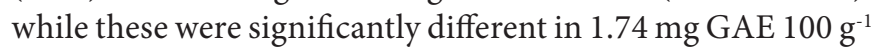
from the recommended dose.

TC contents showed a behavior similar to the one of TSug and contrary to the one of TPC, and were significantly different between sprayed and sprayed + irrigated treatments, in $2 \mathrm{mg}$ $100 \mathrm{~g}^{-1}$. For the doses, the treatments T3 and T4 (1/2 CMV dose) showed higher TC contents than T1 and T2 (dose) and $\mathrm{T} 5$ and T6 (2x CMV dose), in $3.92 \mathrm{mg} 100 \mathrm{~g}^{-1}$ and $5.16 \mathrm{mg}$ $100 \mathrm{~g}^{-1}$, respectively.

ASC contents, in relation to the doses, were also similar to TSug and TC, for which the group T3 and T4 ( $1 / 2$ CMV dose) differed from the others and was superior to the other doses, with differences of $2 \mathrm{mg} 100 \mathrm{~g}^{-1}$ from the mean of T1 and T2 (dose), and $2.75 \mathrm{mg} 100 \mathrm{~g}^{-1}$ from the mean of T5 and T6 (2x CMV dose). For the contrast $\mathrm{C} 1$, the mean ASC content in the conventional treatment was higher than in the organic treatments, with a difference of $2.17 \mathrm{mg} 100 \mathrm{~g}^{-1}$.

For the FOL contents, the contrasts were only significant for the doses. FOL showed a behavior similar to those of TSug, ASC and TC. The highest FOL contents were obtained in T3 and T4 (1/2 CMV dose) and the lowest ones in T5 and T6 (2x CMV dose) with a difference of $1.25 \mathrm{mg} 100 \mathrm{~g}^{-1}$ between the means.
The AC was significantly different in the fruits produced conventionally in $0.07 \mu \mathrm{g} \mathrm{TE} \mathrm{g}{ }^{-1}$, when compared with organic fruits. For the CMV doses, the highest $\mathrm{AC}$ was observed in T5 and T6 (2x CMV dose), which were superior to the other organic doses, with a behavior similar to the one of TPC.

Given the above, the concentration of phenolic compounds and the antioxidant capacity are higher in organic fruits produced with double the recommended dose of cattle manure vermicompost (T5 and T6), in comparison to fruits produced with $1 / 2$ dose (T3 and T4), with a behavior contrary to those of TC, ASC and FOL, which showed higher contents for T3 and $\mathrm{T} 4$ and lower contents for T5 and T6. The interference of the nutrients available was also observed when the treatments with only sprayed biofertilizer produced fruits with more sugar and carotenoids, at the expense of phenolic compounds. When the means of the organic system were compared with the conventional one (T7), the latter only differed for TPC and ASC.

The treatments with $1 / 2$ CMV dose and sprayed biofertilizer, together with the conventional, produced fruits with higher contents of TSug, TC, ASC and FOL, while fruits produced with 2x CMV dose showed higher TPC contents and higher AC.

The mean TPC contents of $12.46 \mathrm{mg} \mathrm{GAE} 100 \mathrm{~g}^{-1}$, for the organic treatments, and $11.03 \mathrm{mg}$ GAE $100 \mathrm{~g}^{-1}$, for the conventional treatment, are lower than the results reported by Barreto (2011), who observed mean value of $140 \mathrm{mg}$ GAE 100 $\mathrm{g}^{-1}$ for 22 melon hybrids and $120 \mathrm{mg} \mathrm{GAE} 100 \mathrm{~g}^{-1}$ for the Goldex hybrid. The contents were relatively low, but range around an expected value for a fruit that is not a rich source of bioactive compounds (Kevers et al., 2007).

On the other hand, the mean values for TC of $19.41 \mathrm{mg}$ $100 \mathrm{~g}^{-1}$ in the organic treatments and $24.83 \mathrm{mg} 100 \mathrm{~g}^{-1}$ in the conventional treatment are much higher than those reported by Barreto (2011), for the same Goldex hybrid (0.39 mg 100 $\left.\mathrm{g}^{-1}\right)$. The author points out that the hybrids with salmon-colored pulp showed the highest mean contents of TC, especially the

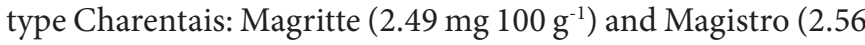
$\left.\mathrm{mg} 100 \mathrm{~g}^{-1}\right)$. As for the composition of TSug, Barreto (2011) also reported mean value of $6.63 \%$ for yellow hybrids and the 
Goldex hybrid showed $7.27 \%$ of TSug and $3.43 \%$ of RSug. The values of TSug and RSug observed in this study were 9.13 and $4.8 \%$, respectively, considering only the organic treatments. These means are higher than those reported by Barreto (2011) and those reported by Tomaz et al. (2009), in different hybrids of yellow melon, who observed values of 7.37 and $8.71 \%$ of TSug and mean value of $4.53 \%$ for RSug.

The highest ASC contents observed in the treatments T7, $\mathrm{T} 3$ and $\mathrm{T} 4$ were $14.9,14.5$ and $14.13 \mathrm{mg} 100 \mathrm{~g}^{-1}$, respectively. The ASC contents reported in the literature are very diverse; Barreto (2011) observed ASC mean values of $4.75 \mathrm{mg} 100 \mathrm{~g}^{-1}$ for hybrids of yellow melon and $4.26 \mathrm{mg} 100 \mathrm{~g}^{-1}$ for the hybrid Goldex, the object of this study. In comparison to the mean value of $12.73 \mathrm{mg} 100 \mathrm{~g}^{-1}$ found for the organic treatments, these values are $198.8 \%$ higher; however, Silva et al. (2010)

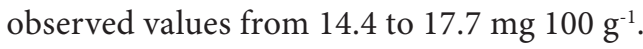

Aroucha et al. (2007) observed values of 19.01, 36.96, 24.64 and $48.40 \mathrm{mg} 100 \mathrm{~mL}^{-1}$ for the melons AF 1749, Hymark, Rochedo and Caipira. Vargas et al. (2008), studying the muskmelon hybrids 'Maxim, 'Bônus n²', 'Shinju 200', 'Fantasy' and 'Louis', as a function of the cultivation system (substrate and soil), observed a mean content of $15.77 \mathrm{mg}$ of vitamin C $100 \mathrm{~mL}^{-1}$, for the cultivation in soil. Kevers et al. (2007) observed $4 \mathrm{mg}$ of vitamin C $100 \mathrm{~g}^{-1}, 70 \mathrm{mg} \mathrm{GAE} 100 \mathrm{~g} \mathrm{~g}^{-1}$ for TPC and $56 \mu$ tem $100 \mathrm{~g}^{-1}$ for $\mathrm{AC}$, in Charentais melons. These values do not agree with the ones in this study, but refer to aromatic types of melon, in which the levels of secondary compounds are naturally higher.

Similarly to what occurred with TPC, the contents of ASC, a precursor of vitamin C, are highly variable among the reports; this is due to methods of detection and quantification, genotypes, cultivation systems and maturation stage, among other factors (Alhagdow et al., 2007). In addition, most of the cited studies (Aroucha et al., 2007; Vargas et al., 2008; Barreto, 2011) used vitamin $C$ data obtained using a method that is not equivalent to the one used in this study, the HPLC.

The differences between the results of phenolic compounds and ascorbic acid observed here and those widely variable among the cited references can also have a hypothetical explanation. Holistic studies (Alhagdow, et al., 2007; Oh et al., 2009; Aluru et al., 2009; Borowski et al., 2014) on integrative metabolomics have shown that the adaptive mechanisms of plants follow the logic of cell homeostasis, with maximum economy, i.e., when a protection metabolism is induced, another one is saved. In this case, for example, the studied melons show relatively high values of ascorbic acid, but relatively low values of total phenolic compounds. It is possible, through the metabolic perspective, that the melons have directed their defense priorities to one of the aforementioned metabolic pathways, since both produce polar metabolites, highly reactive to reactive oxygen species. This claim is made based on studies that show that, when a plant protects itself with a group of metabolites, it saves others (Borowski et al., 2014). This claim is also true when slightly polar metabolites are compared, such as the carotenoids. The synthesis of these compounds, besides genotypic and environmental interferences, is the result of the metabolic balance, i.e., they are produced to establish the antioxidant balance between hydrophilic and hydrophobic molecules (Alhagdow et al.,
2007; Aluru et al., 2009). Thus, finding high values of ASC and TC is consistent; similarly, finding high contents of ASC and relatively low contents of TPC is a reasonable physiological tendency.

The AC was higher in the organic treatments with $2 \mathrm{x} C M V$ dose, with mean value of $19.2 \mu \mathrm{g} \mathrm{TE} \mathrm{g}^{-1}$, while treatments with $1 / 2 \mathrm{CMV}$ dose and the conventional treatment showed lower values (15.17 and $17.43 \mu \mathrm{g} \mathrm{TE} \mathrm{g}^{-1}$, respectively). Barreto (2011) observed mean value of $0.67 \mu \mathrm{M} \mathrm{TE} \mathrm{g}^{-1}$ among 22 commercial hybrids evaluated. The yellow melons showed mean values below the overall mean, with $\mathrm{AC}$ of $0.41 \mu \mathrm{M} \mathrm{TE} \mathrm{g}^{-1}$ and the hybrid Goldex showed a value of $0.43 \mu \mathrm{M}$ TE $g^{-1}$.

The AC was influenced by the type and by the dose of fertilization, as occurred for the TPC contents. These results agree with those described in the literature (Toor et al., 2006; Wang et al, 2008; Perin et al., 2014), which claim that products from organic production systems can have higher amounts of TPC. In addition, the different fertilizations used in the organic system influenced the behavior of these variables.

Most studies report similar tendencies. For example, Arbos et al. (2010) compared the AC and TPC contents between lettuce, rocket and chicory, in organic and conventional cultivation, and observed that the organic system contributed, simultaneously, to the highest TPC content and a more effective AC for all the evaluated species. In addition, mango fruits from conventional systems showed lower contents of phenolic compounds, flavonoids, antioxidant capacity, lower concentration of soluble solids, total and reducing sugars and fixed mineral residue in comparison to the fruits from organic and biodynamic cultivation systems (Maciel et al., 2011). Wang et al. (2008), when evaluating organic and conventional cultivations of blueberry, concluded that the contents of total phenolic compounds, flavonoids and antioxidant capacity were higher in the organic cultivation.

Further studies are still needed in order to better elucidate the interferences from the use of biofertilizers on plant metabolism, development and defense.

\section{Conclusions}

1. Organic and conventional cultivation systems influenced the postharvest quality, especially regarding the composition of phytochemical compounds.

2. The organic management with $1 / 2$ the recommended dose of cattle manure vermicompost (237.5 g) plus the sprayed biofertilizer and the management with conventional fertilization produced more balanced fruits, with higher phytochemical quality, higher contents of sugars, total carotenoids, ascorbic acid and folates.

3. The organic management with double the recommended dose of cattle manure vermicompost ( $950 \mathrm{~g}$ ) produced fruits with higher contents of phenolic compounds and higher antioxidant capacity.

\section{ACknowledgments}

To the University of the Campanha Region and to the Post Graduate Program in Agricultural Family Production Systems 
of the Federal University of Pelotas, the National Council for Scientific and Technological Development (CNPq) and to the Secretariat of Science, Technology and Innovation (SCTI - RS), for the financial support to this research.

\section{Literature CITED}

ABF - Anuário Brasileiro de Fruticultura. Santa Cruz do Sul: Gazeta Santa Cruz, 2014. 136p.

Alhagdow, M.; Mounet, F.; Gilbert, L.; Nunes-Nesi, A.; Garcia, V.; Just, D.; Petit, J.; Beauvoit, B.; Fernie, A. R.; Rothan, C.; Baldet, P. Silencing of the mitochondrial ascorbate synthesizing enzyme l-galactono-1,4-lactone dehydrogenase affect plant and fruit development in tomato. Plant Physiology, v.145, p.1408-1422, 2007. http://dx.doi.org/10.1104/pp.107.106500

Aluru, M. R.; Zola, J.; Foudree, A.; Rodermel, S. R. Chloroplast photooxidation induced transcriptome reprogramming in arabidopsis immutans white leaf sectors. Plant Physiology, v.150, p.904-923, 2009. http://dx.doi.org/10.1104/pp.109.135780

AOAC - Association of Official Agricultural Chemistry. 11th ed. Washington: AOAC, 1992. 1115p.

Arbos, K. A.; Freitas, R. J. S. de; Stertz, C. S. C.; Dornas, M. F. Antioxidant activity and phenolic content in organic and conventional vegetables. Food Science and Technology, v.30, p.501-506, 2010. http://dx.doi.org/10.1590/S0101-20612010000200031

Aroucha, E. M. M.; Morais, F. A. de.; Nunes, G. H. S.; Tomaz, H. V. de Q.; Sousa, A. E. D. de.; Neto, F. B. Caracterização física e química de melão durante o seu desenvolvimento. Revista Brasileira de Fruticultura, v.29, p.296-301, 2007. http://dx.doi.org/10.1590/ S0100-29452007000200021

Balisteiro, D. M.; Rombaldi, C. V.; Genovese, M. I. Protein, isoflavones, trypsin inhibitory and in vitro antioxidant capacities:Comparison among conventionally and organically grown soybeans. Food Research International, v.51, p.8-14, 2013. http://dx.doi. org/10.1016/j.foodres.2012.11.015

Barreto, N. D. S. Qualidade, compostos bioativos e capacidade antioxidante de frutos de híbridos comerciais de meloeiro cultivados no CE e RN. Mossoró: UFERSA. 2011. 185p. Tese Doutorado

Borowski, J. M.; Galli, V.; Messias, R. da. S.; Perin, E. P.; Buss, J. H.; Silva, S. D. dos. A. E.; Rombaldi, C. V. Selection of candidate reference genes for real-time PCR studies in lettuce under abiotic stresses. Planta, v.239, p.1187-1200, 2014.

Catharino, R. R.; Godoy, H. T.; Lima-Pallone, J. A. Metodologia analítica para determinação de folatos e ácido fólico em alimentos. Química Nova, v.29, p.972-976, 2006. http://dx.doi.org/10.1590/ S0100-40422006000500016

Fetter, M. R.; Vizzotto, M.; Corbelini, D.; Gonzalez, T. N. Compostos bioativos e atividade antioxidante em Araçá Amarelo, Araçá Vermelho (Psidium cattleyanum Sabine) e Araçá-Pêra ( $P$. Acutangulum D.C.) cultivados em Pelotas, RS. Brazilian Journal of Food Technology, v.3, p.92-95, 2010. http://dx.doi. org/10.4260/BJFT20101304115

Filgueiras, H. A. C.; Menezes, J. B.; Alves, R. E.; Costa, F. V.; Pereira, L. S. E.; Gomes Júnior, J. Colheita e manuseio pós-colheita. In: Alves, R. E. (org.). Melão pós-colheita. Brasília: Embrapa SPI, 2000. p.23-41. Frutas do Brasil, 10
Kevers, C.; Falkowski, M.; Tabart, J.; Defraigne, J. O.; Dommes, J.; Pincemail, J. Evolution of antioxidant capacity during storage of selected fruits and vegetables. Agricultural Food Chemistry, v.55, p.8596-8603, 2007. http://dx.doi.org/10.1021/jf071736j

Lester, G. E.; Hodges, D. M. Antioxidants associated with fruit senescence and human health: Novel orange-fleshed non-netted honey dew melon genotype comparisons following different seasonal productions and cold storage durations. Postharvest Biology and Technology, v.48, p.347-354, 2008. http://dx.doi. org/10.1016/j.postharvbio.2007.11.008

Maciel, L. F.; Oliveira, C. S.; Bispo, E. S.; Miranda, M. P. S. Antioxidant activity, total phenolic compounds and flavonoids of mangoes coming from biodynamic, organic and conventional cultivations in threematuration stages. British Food Journal, v.113, p.11031113, 2011. http://dx.doi.org/10.1108/00070701111180319

Menezes, J. B.; Chitarra, A. B.; Chitarra, M. I.; Bicalho, U. O. Qualidade do melão tipo Galia durante a maturação. Horticultura Brasileira, v.16, p.123-127, 1998.

Oh, M. M.; Trick, H. N.; Rajashekar, C. B. Secondary metabolism and antioxidants are involved in environmental adaptation and stress tolerance in lettuce. Journal Plant Physiology, v.166, p.180-191, 2009. http://dx.doi.org/10.1016/j.jplph.2008.04.015

Perin, E. C.; Schott, I. B.; Pinto, E. P.; Manfroi, V.; Rombaldi, C. V.; Zanuzo, M. R.; Lucchetta, L. Resveratrol and bioactive properties in table wines from organic and conventional production system. Scientific Electronic Archives, v.5, p.39-46, 2014.

Podsedek, A. Natural antioxidants and antioxidant capacity of Brassica vegetables: A review. LWT - Food Science Technology, v.40, p.111, 2007. http://dx.doi.org/10.1016/j.lwt.2005.07.023

Rodriguez-Amaya, D. B. A guide to carotenoid analysis in foods. Washington: ILSI Human Nutrition Institute. 2001. 63p.

ROLAS - Rede Oficial de Laboratórios de Análise de Solo e de Tecido Vegetal. Manual de adubação e calagem para os estados do Rio Grande do Sul e Santa Catarina. 10.ed. Porto Alegre: Sociedade Brasileira de Ciência do Solo, 2004. 400p.

Silva, M. L.; Costa, R. S.; Santana, A. S. dos; Koblitz, M. G. B. Compostos fenólicos, carotenóides e atividade antioxidante em produtos vegetais. Semina: Ciências Agrárias, v.31, p.669-682, 2010. http://dx.doi.org/10.5433/1679-0359.2010v31n3p669

Statistix 9, Analytical Software, Copyright ${ }^{\oplus} .1985-2008$. Version 9.0, 2009.

Swain, T.; Hillis, W. T. The phenolic constituents of Prunnus domestica. Journal of the Science of Food and Agriculture, v.10, p.135-144, 1959.

Tomaz, H. V. de Q.; Aroucha, E. M. M.; Nunes, G. H. de S.; Bezerra Neto, F.; Tomaz, H. V. de Q.; Queiroz, R. F. Qualidade pós-colheita de diferentes híbridos de melão-Amarelo armazenados sob refrigeração. Revista Brasileira de Fruticultura, v.31, p.987-994, 2009. http://dx.doi.org/10.1590/S0100-29452009000400011

Toor, R. K.; Savage, G. P.; Heeb, A. Influence of different types of fertilizers on the major antioxidant components of tomatoes. Journal of Food Composition and Analysis, v.19, p.20-27, 2006. http://dx.doi.org/10.1016/j.jfca.2005.03.003

Vargas, P. F.; Castoldi, R.; Charlo, H. C. O.; Braz, L. T. Qualidade de melão rendilhado (Cucumis melo L.) em função do sistema de cultivo. Ciência e Agrotecnologia, v.32, p.137-142. 2008. http:// dx.doi.org/10.1590/S1413-70542008000100020 
Vinci, G.; Botre, F.; Mele, G. Ascorbic acid in exotic fruits: a liquid chromatographic investigation. Food Chemistry, v.53, p.211-214, 1995. http://dx.doi.org/10.1016/0308-8146(95)90791-5

Wang, S. Y.; Chen, C. T.; Sciarappa, W.; Wang, C. Y.; Camp, M. J. Fruit quality,antioxidant capacity, and flavonoid content of organically and conventionally grown blueberries. Journal of Agricultural and Food Chemistry, v.56, p.5788-5794, 2008. http://dx.doi.org/10.1021/jf703775r
Willer, H.; Lernoud, J.; Kilcher, L. The world of Organic Agriculture - Statistics \& Emerging Trends. FIBL - IFOAM Report. 340p. 2013. http://www.Organic-world.net/yearbook-2013.html? \&L=0. 20 Mar. 2014.

Williams, C. M. Nutritional quality of organic food: shades of grey or shades of green? Proceedings of the Nutrition Society, v.61, p.19-24, 2002. http://dx.doi.org/10.1079/PNS2001126 